\title{
KETERKAITAN SEKTOR PERIKANAN DALAM PEREKONOMIAN INDONESIA: PENDEKATAN MODEL INPUT-OUTPUT
}

\author{
Oleh: \\ Tajerin, Risna Yusuf, Sastrawidjaja dan Asnawi *
}

\begin{abstract}
Keterkaitan sektor perikanan dalam perekonomian nasional akan menentukan peran strategis sektor tersebut dalam pembangunan perikanan dan pemulihan perekonomian nasional. Untuk itu telah dilakukan kajian mengenai keterkaitan sektor perikanan "dalam arti luas" dengan menggunakan metode analisis keterkaitan ke belakang (backward lingkage) dan ke depan (forward lingkage) berdasarkan pendekatan model input output. Data yang digunakan dalam kajian ini adalah data sekunder dari table input output tahun 1990, 1995 dan 2000. Hasil kajian menunjukkan bahwa selama periode 1990-2000, secara rata-rata keterkaitan sektor perikanan dalam perekonomian nasional masih relatif lemah dengan indeks keterkaitan berkisar sebesar 0,46-1,10. Kecenderungan penguatan keterkaitan ke belakang terjadi pada perikanan darat, sedangkan penguatan keterkaitan ke depan terjadi pada industri pengolahan dan pengawetan ikan. Selain itu, keterkaitan antara kelompok perikanan primer (perikanan laut dan perikanan darat) dan kelompok perikanan sekunder (industri pengeringan dan penggaraman ikan dan industri pengolahan dan pengawetan ikan) lebih mencerminkan keterkaitan ke depan berupa aliran pasokan komoditas ikan untuk bahan baku. Namun keterkaitan itu masih relatif lemah dan cenderung semakin lemah.
\end{abstract}

\section{Kata Kunci: Perikanan, Industri, Keterkaitan}

Abstract: Fisheries Sector Linkages in The National Economy: An Input-Output Approach. By: Tajerin, Risna Yusuf, Sastrawidjaja and Asnawi.

Fisheries sector linkage in National Economy will determine the strategic roles of the sector for its development and National Economic recovery. In line with this, a study was conducted to determine backward and forward linkage of the sector using input output model approach. Secondary data were used, that are input output tables of the year 1990, 1995 and 2000. The results of the study showed that during the period of 1990 - 2000, the average linkage of these sector in National economy are relatively weak with the index of linkage approximately of 0,46-1,10. Stronger backward linkage was observed in inland fisheries, while stronger forward linkage demonstrated on industrial fish processing and preservation. The linkage of primary fisheries group (sea and inland fisheries) to the secondary fisheries group (industrial fish processing) indicating the forward linkage such as fish supply as raw materials. However, the linkage is relatively weak.

\section{Keywords: Fishery, Industry, Linkages}

\footnotetext{
* Peneliti Pada Balai Besar Riset Sosial Ekonomi Kelautan dan Perikanan, BRKP-DKP.

JI. KS TUBUN Petamburan VI Slipi Jakarta 10260. Telp. (021) 53650159
} 


\section{PENDAHULUAN}

Indonesia dewasa ini tengah dihadapkan pada salah satu dampak globalisasi dimana keterkaitan ekonomi suatu negara terhadap negara lain serta bebasnya mobilisasi faktor produksi termasuk modal, menyebabkan Indonesia mengalami krisis ekonomi yang berkepanjangan. Oleh karena itu, tantangan paling besar bangsa untuk Indonesia saat ini adalah bagaimana membangkitkan kembali (revitalisasi) perekonomian nasional melalui penggalian sumber-sumber pertumbuhan ekonomi baru atau peningkatan sumber pertumbuhan yang selama ini berlangsung.

Salah satu sumber pertumbuhan yang diharapkan dapat menolong bangsa ini keluar dari krisis ekonomi dan menghantarkan menjadi bangsa yang maju adalah sub sektor perikanan. Keyakinan tersebut berdasarkan pada tiga alasan utama. Pertama, fakta fisik menunjukkan bahwa Indonesia merupakan negara kepulauan terbesar di dunia yang terdiri dari 17.504 pulau dengan garis pantai sepanjang $81.000 \mathrm{~km}$ dan luas laut sekitar 5,7 juta $\mathrm{km}^{2}$ atau 62 persen dari luas teritorialnya (Dahuri et al., 2001). Kedua, di wilayah pesisir dan lautan yang sangat luas itu terdapat sumberdaya alam yang besar sebagai potensi pembangunan yang belum termanfaatkan secara optimal. Ketiga, bahwa seiring dengan pertambahan jumlah penduduk dunia, permintaan terhadap produk-produk perikanan baik yang berasal dari pasar domestik maupun pasar global diperkirakan akan semakin meningkat.

Melihat kondisi tersebut, pemerintah dalam hal ini Departemen Kelautan dan Perikanan (DKP) telah melakukan langkahlangkah strategis melalui pengembangan program revitalisasi di bidang perikanan yang mencakup revitalisasi sumber-sumber pertumbuhan ekonomi yang ada seperti kegiatan usaha di bidang penangkapan ikan dan budidaya perikanan serta mengoptimalkan operasionalisasi unit usaha pengolahan ikan dalam negeri.

Dari cakupan program revitalisasi perikanan tersebut, terungkap pentingnya melakukan pengintegrasian secara vertikal antara kegiatan usaha di kelompok perikanan primer, baik sub sektor perikanan budidaya maupun sub sektor perikanan tangkap sebagai penyedia bahan baku dengan kelompok perikanan sekunder baik sub sektor industri pengeringan dan penggaraman ikan maupun sub sektor industri pengolahan dan pengawetan ikan sebagai pengguna dari bahan baku tersebut. Kurang terintegrasinya kedua kelompok perikanan tersebut diduga menjadi salah satu penyebab penurunan utilitas dan kapasitas produksi dari kelompok perikanan sekunder, bahkan hilangnya potensi penerimaan baik di sektor privat maupun publik. Hubungan simbiosis yang terjadi dari kedua kelompok perikanan tersebut, pada gilirannya dapat menumbuhkan derajat sinergis dalam meningkatan produktivitas dan kontribusi nilai tambah secara keseluruhan bagi perekonomian nasional.

Derajat atau kekuatan integrasi kelompok perikanan primer dengan kelompok perikanan sekunder atau sektor industri lainnya dalam perekonomian akan menentukan apakah sektor perikanan adalah merupakan sektor strategis atau tidak. Semakin kuat kelompok perikanan primer terintegrasi dengan kelompok perikanan sekunder, maka akan semakin strategis sektor perikanan tersebut. Dengan demikian bila kelompok perikanan primer dikembangkan maka dengan sendirinya kelompok perikanan sekunder akan juga berkembang. Sebaliknya bila kelompok perikanan sekunder dikembangkan, maka kelompok perikanan primer juga akan berkembang (Nikijuluw, 2005).

Penyempurnaan proses industrialisasi yang memposisikan kelompok perikanan sekunder sebagai lokomotif bagi pertumbuhan 
ekonomi kelompok perikanan primer, selaras dengan upaya perbaikan paradigma pembangunan yang mengintegrasikan secara vertikal antara kedua kelompok perikanan tersebut dengan menerapkan strategi Agricultural Demand Led Industrialization (ADLI). Diharapkan melalui upaya penyempurnaan dan perbaikan tersebut dapat lebih memberikan dorongan dalam menggerakkan sektor-sektor hulu maupun hilir, sehingga secara makro melalui kecenderungan adanya peningkatan keterkaitan mampu menciptakan peningkatan produktivitas dan nilai tambah dari kegiatan ekonomi, khususnya di kedua kelompok perikanan tersebut, yang pada akhirnya dapat memberikan sumbangan bagi percepatan pemulihan perekonomian di Indoensia.

Oleh karena itu, kajian ini dilakukan untuk mengetahui sejauhmana keterkaitan antara kegiatan ekonomi di kelompok perikanan primer dan kelompok perikanan sekunder dalam perekonomian Indonesia secara keseluruhan. Hasil kajian ini diharapkan dapat berguna sebagai bahan masukan bagi peningkatan efektifitas kebijakan terkait dengan revitalisasi di sektor perikanan melalui penguatan derajat keterkaitannya.

\section{METODE}

\section{Landasan Teoritis}

Adelman (1984) menekankan pentingnya Agricultural Demand Led Industrialization (ADLI). Dengan sejumlah analisis, ia berhasil membuktikan bahwa strategi ADLI lebih superior dibanding strategi export led growth, khususnya apabila diterapkan di negara sedang berkembang di mana peranan sektor pertanian masih sangat penting. Strategi ini menghendaki pergeseran strategi pertanian dari surplus extraction menjadi surplus creation, dan ditumbuhkannya keterkaitan permintaan antara sektor pertanian dengan sektor lain dalam perekonomian. Pandangan ini sejalan dengan pemikiran Sumodiningrat dan Kuncoro (1991) yang mencoba menuangkan pola simbiosis antara sektor pertanian dan industri melalui strartegi pengembangan agroindustri dan agribisnis. Relevan dengan pemikiran tersebut, upaya mendinamiskan sub sektor perikanan sebagai salah satu bagian dari sektor pertanian melalui kekuatan keterkaitannya dengan sub sektor industri pengolahan hasil perikanan merupakan hal yang menarik untuk dikaji.

Banyak ahli yang sependapat bahwa salah satu syarat perlu (necessary condition) untuk dapat dicapainya transformasi struktural atau perubahan struktur dari pertanian (sektor primer) ke industri manufaktur (sektor sekunder) adalah adanya keterkaitan sektor pertanian dan sektor industri yang tangguh. Bagi sektor perikanan, kaitan yang paling sesuai adalah industri pengolahan hasil-hasil perikanan ke dalam pengembangan agroindustri perikanan.

Pandangan Adelman mengenai pengembangan sektor pertanian termasuk di dalamnya sektor perikanan berbeda dengan Hirschman dalam Jhingan (1991). Hirschman memandang sektor pertanian sebagai sektor yang pasif, sementara Adelman sebaliknya. Perbedaan pandangan itu terletak pada kriteria pemilihan sektor kunci (leading sector) dalam akselerasi pembangunan. Kriteria yang digunakan Hirschman dalam menentukan sektor kunci tersebut menurut pandangan Adelman terlalu sempit karena hanya mempertimbangkan keterkaitan produk, yang jelas akan menempatkan sektor pertanian pada sektor inferior. Padahal kenyataannya berdasarkan hasil penelitian Rangrajan (1982); Bell dan Hazell (1980); Adelman (1984); Haggblade et al. (1991); Haggblade dan Hazell (1989); Cavallo dan Mundlak (1982), menunjukkan bahwa keterkaitan antara sektor pertanian dengan sektor industri tidak hanya keterkaitan produk, tetapi ada 
media keterkaitan lainnya yaitu: keterkaitan konsumsi, investasi dan tenaga kerja yang mampu menjelaskan secara lebih menyeluruh mengenai keterkaitan kedua sektor tersebut.

Di beberapa negara yang mengandalkan pertanian sebagai sektor andalan dalam perekonomian nasionalnya, keterkaitan tersebut terbukti memberikan kemajuan yang berarti, seperti Costa Rica (Celes dan Lizano, 1995); Colombia (Berry, 1995); Kenya (Bigsten dan Collier, 1995); Argentina (Mundlak dan Donenech, 1995); dan India (Bhalla, 1995).

\section{Jenis dan Sumber Data}

Data yang digunakan dalam kajian ini adalah data sekunder dari buku Tabel InputOuput Tahun 1990, 1995 dan 2000 yang disusun oleh Badan Pusat Statistik (1994, 1999, 2004) berupa "tabel transaksi domestik atas dasar harga produsen dalam satuan jutaan rupiah". Untuk dapat merekam keterkaitan sektor perikanan "dalam arti luas", dilakukan rancangan/modifikasi tabel input output yang digunakan dengan merinci sektor perikanan menjadi kelompok perikanan primer dan kelompok perikanan sekunder. Kelompok perikanan primer dalam hal ini meliputi:

(1) sub sektor perikanan laut dan hasil laut lainnya; dan
(2) sub sektor perikanan darat dan hasil perairan darat lainnya.

Sedangkan kelompok perikanan sekunder meliputi:

(1) sub sektor industri pengeringan dan penggaraman ikan dan biota perairan lainnya, dan

(2) sub sektor industri pengolahan dan pengawetan ikan dan biota perairan lainnya.

Agar rancangan/modifikasi tabel input output seperti tersebut dapat tercapai, dalam kajian ini digunakan Tabel input-output menurut klasifikasi 161 x 161 sektor untuk tahun 1995; $172 \times 172$ sektor untuk tahun 1995; dan 175 x 175 sektor untuk tahun 2000. Selanjutnya masing-masing tabel tersebut diklasifikasi kembali (reklasifikasi) dengan menggunakan teknik agregasi, sehingga menjadi matriks dengan klasifikasi $9 \times 9$ sektor, seperti tertera pada Tabel 1.

\section{Metoda Analisis Data}

Dalam kajian ini analisis keterkaitan dilakukan melalui konsep total keterkaitan yang disarankan dan digunakan oleh Nazara (1997) dan West, 1992), dimana masingmasing keterkaitan tersebut baik total keterkaitan ke belakang (Total of Backward Linkages) maupun total keterkaitan ke depan

Tabel 1. Pengklasifikasian Sektoral Tabel Input-Output Menjadi Klasifikasi Matriks Ukuran $9 \times 9$ Sektor, Indonesia, 1990-2000

Table 1. Sectors Reclassification from Input Output Table of Indonesia 1999 - 2000 to be 9 × 9 Sectors Matrix Classification

\begin{tabular}{|c|c|c|c|c|}
\hline \multirow[t]{2}{*}{$\begin{array}{l}\text { Sektorl } \\
\text { Sector }\end{array}$} & \multirow[t]{2}{*}{$\begin{array}{l}\text { Deskripsi/ } \\
\text { Description }\end{array}$} & \multicolumn{3}{|c|}{$\begin{array}{l}\text { Sektor-Sektor dalam Tabel Input-Output / } \\
\text { Sectors in Input Output Table }\end{array}$} \\
\hline & & 1990 & 1995 & 2000 \\
\hline 1 & $\begin{array}{l}\text { Pertanian Non Perikanan/ Agriculture } \\
\text { Non Fisheries }\end{array}$ & $1-28$ & $1-31$ & $1-30$ \\
\hline 2 & $\begin{array}{l}\text { Perikanan Primer/Primary Fisheries: } \\
\text { - Sub Sektor Perikanan Laut dan Hasil } \\
\text { Perairan Laut Lainnya/ Marine } \\
\text { Fisheries Sub Sector and Other Marine }\end{array}$ & 29 & $32 ; 34 L_{90}$ *) & $31 ; 33 \mathrm{~L}_{00^{* * *}}$ \\
\hline 3 & $\begin{array}{l}\text { Fisheries Product } \\
\text { - Sub Sektor Perikanan Darat dan Hasil } \\
\text { Perairan Darat Lainnya/Inland } \\
\text { Fisheries Sub Sector and Other Inland } \\
\text { Fisheries Product }\end{array}$ & 30 & 33; $34 \mathrm{D}_{90}{ }^{* *)}$ & $\left.32 ; 33 D_{00}{ }^{* * * *}\right)$ \\
\hline
\end{tabular}


Tabel 1. lanjutan/Table 1. continued

\begin{tabular}{|c|c|c|c|c|}
\hline \multirow[t]{2}{*}{$\begin{array}{l}\text { Sektorl } \\
\text { Sector }\end{array}$} & \multirow[t]{2}{*}{$\begin{array}{l}\text { Deskripsi/ } \\
\text { Description }\end{array}$} & \multicolumn{3}{|c|}{$\begin{array}{c}\text { Sektor-Sektor dalam Tabel Input-Output I } \\
\text { Sectors in Input Output Table }\end{array}$} \\
\hline & & 1990 & 1995 & 2000 \\
\hline & $\begin{array}{l}\text { Perikanan Sekunder/ Secondary } \\
\text { Fisheries: }\end{array}$ & & & \\
\hline 4 & $\begin{array}{l}\text { - Sub Sektor Industri Pengeringan dan } \\
\text { Penggaraman Ikan dan Biota Perairan } \\
\text { Lainnya/ Sub Sector Dried and Salted } \\
\text { Processing Industries }\end{array}$ & 31 & 53 & 53 \\
\hline 5 & $\begin{array}{l}\text { - Sub Sektor Industri Pengolahan dan } \\
\text { Pengawetan Ikan dan Biota Perairan } \\
\text { Lainnya/Sub Sector Processing and } \\
\text { Preserving Industries }\end{array}$ & 48 & 54 & 54 \\
\hline 6 & $\begin{array}{l}\text { Pertambangan dan Penggalian/ Mining } \\
\text { and Quarrying }\end{array}$ & $32-34$ & $36-48$ & $35-48$ \\
\hline 7 & $\begin{array}{l}\text { Industri Pengolahan Hasil Pertanian Non } \\
\text { Perikanan/ Agriculture Non Fisheries } \\
\text { Processing Industries }\end{array}$ & $47-47 ; 49-83$ & $49-52 ; 55-91$ & $49-52 ; 55-93$ \\
\hline 8 & $\begin{array}{l}\text { Industri Pengolahan Lainnya/ } \\
\text { Other Processing Industries }\end{array}$ & $84-131$ & $92-139$ & $94-141$ \\
\hline 9 & Jasa dan Lainnya/ Service and Others & $132-161$ & $35 ; 140-172$ & $34 ; 142-175$ \\
\hline
\end{tabular}

Keterangan:

*) Proporsi output sektor 34 (udang) untuk sektor 29 sebesar 54,1\% yang berasal dari udang hasil tangkapan di laut pada tahun 1995 (BPS, 2004b)

**) Proporsi output sektor 34 (udang) untuk sektor 30 sebesar 45,9\% yang berasal dari udang hasil budidaya tambak dan tangkapan di perairan umum pada tahun 1995 (BPS, 2004b)

***) Proporsi output sektor 34 (udang) untuk sektor 29 sebesar 54,5\% yang berasal dari udang hasil tangkapan di laut pada tahun 2000 (BPS, 2004b)

****) Proporsi output sektor 34 (udang) untuk sektor 30 sebesar $54,5 \%$ yang berasal dari udang hasil budidaya tambak dan tangkapan di perairan umum pada tahun 2000 (BPS, 2004b)

Remarks:

*) Output proportion of 34 sectors (Shrimp) for 29 sectors is 54,1\% from Shrimp from marine in 1995 (BPS, 2004b)

**) Output proportion of 34 sectors (shrimp) for 30 sectors is 45,9\% from Shrimp from brackiswater pond and in land water in 1995 (BPS, 2004b)

${ }^{* * *}$ ) Output proportion of 34 sectors (shrimp) for 29 sectors is $54,5 \%$ from marine in 2000 (BPS, 2004b)

****) Output proportion of 34 sectors (shrimp) for 30 sectors is $54,5 \%$ from brachkiswater pond and inland in 2000 (BPS, 2004b).

(Total of Forward Linkages), masing-masing merupakan penjumlahan dari keterkaitan langsung dan keterkaitan tidak langsung. Secara rinci uraian jenis-jenis keterkaitan tersebut adalah sebagai berikut:

\section{Koefisien keterkaitan langsung ke belakang}

Keterkaitan langsung ke belakang menunjukkan seberapa banyak input yang berasal dari produksi sektor lain yang digunakan oleh sektor tertentu dalam proses produksinya. Besaran keterkaitan langsung ke belakang diperoleh dengan menjumlahkan elemen-elemen dalam satu kolom matriks koefisien teknologi. Secara matematis keterkaitan langsung ke belakang tersebut diformulasikan sebagai berikut:

$$
D B L(d)_{j}=a_{1 j}+a_{2 j}+\ldots+a_{n j}=\sum_{j=1}^{n} a_{i j}
$$

dimana: $D B L(d)_{j}=$ daya penyebaran tidak langsung sektor $j$ 
2. Koefisien keterkaitan tidak langsung ke belakang

Secara umum keterkaitan tidak langsung ke belakang menunjukkan jumlah dampak yang ditimbulkan akibat perubahan permintaan akhir suatu sektor terhadap output seluruh ekonomi, sehingga secara matematis diformulasikan sebagai berikut:

$$
\operatorname{IBL}(d)_{j}=\alpha_{1 j}+\alpha_{2 j}+\ldots+\alpha_{n j}=\sum_{j=1}^{n} \alpha_{i j}
$$

dimana:

$$
\begin{aligned}
I B L(d)_{j}= & \text { jumlah dampak akibat perubahan } \\
& \text { permintaan akhir sektor } j \\
& \text { terhadap output seluruh sektor } \\
& \text { ekonomi atau jumlah daya } \\
& \text { penyebaran langsung } \\
\alpha_{i j}= & \text { matriks kebalikan Leontief pada } \\
& (I-A)^{-1} \text { baris } i \text { dan kolom } j
\end{aligned}
$$

\section{Koefisien keterkaitan langsung ke depan}

Keterkaitan langsung ke depan menunjukkan seberapa banyak output suatu sektor tertentu yang digunakan oleh sektor lain sebagai input. Besaran keterkaitan langsung ke belakang diperoleh dengan menjumlahkan elemen-elemen dalam satu baris dari matriks koefisien teknoligi (A). Secara matematis keterkaitan langsung ke depan diformluasikan sebagai berikut:

$$
\operatorname{DFL}(d)_{i}=a_{1 j}+a_{2 j}+\ldots+a_{n j}=\sum_{i=1}^{n} a_{i j}
$$

4. Koefisien keterkaitan tidak langsung ke depan

Jumlah dampak terhadap output sektor $i$ sebagai akibat perubahan permintaan akhir berbagai (seluruh) sektor dapat dituliskan:

dimana:

$$
\operatorname{IFL}(d)_{i}=\sum_{j} \alpha_{i j}
$$

$$
\begin{aligned}
\operatorname{IFL}(d)_{i}= & \text { jumlah dampak terhadap sektor i } \\
& \text { sebagai akibat perubahan seluruh } \\
& \text { sektor atau disebut derajat } \\
& \text { kepekaan }
\end{aligned}
$$

Selanjutnya untuk keperluan perbandingan keterkaitan sektor yang diamati dengan rata-rata keseluruhan sektor dalam perekonomian nasional, dilakukan perhitungan indeks keterkaitan ke belakang (daya penyebaran) dan indeks keterkaitan ke depan (daya kepekaan). Secara rinci uraian kedua jenis indeks tersebut adalah sebagai berikut:

4.1. Indeks keterkaitan total ke belakang (daya penyebaran total)

Indeks daya penyebaran memberikan gambaran tentang pengaruh yang ditimbulkan oleh satu unit permintaan akhir untuk semua sektor di dalam perekonomian nasional. Sehingga secara matematis dapat diformulasikan sebagai berikut:

$$
I D P_{j}=\frac{\sum_{i} T B L_{i j}}{\left(\frac{1}{n}\right) \sum_{i} \sum_{j} T B L_{i j}}
$$

dimana:

IDP $j=$ indeks daya penyebaran sektor ke- $j$ $\mathrm{TBL} i j=$ total keterkaitan ke belakang (penjumlahan dari keterkaitan langsung ke belakang dan keterkaitan tidak langsung ke belakang) dari sektor $i$ ke sektor $j$

$n$

$=$ jumlah sektor dalam tabel input output yang dianalisis

4.2. Indeks keterkaitan total ke depan (derajat kepekaan total)

Indeks keterkaitan ke depan (derajat kepekaan) menunjukkan pengaruh yang ditimbulkan oleh satu unit permintaan akhir terhadap semua sector dalam perekonomian nasional. Sehingga secara matematis dapat diformulasikan sebagai berikut:

$$
I D K_{i}=\frac{\sum_{j} T F L_{i j}}{\left(\frac{1}{n}\right) \sum_{i} \sum_{j} T F L_{i j}}
$$

dimana:

IDP $i=$ indeks derajat kepekaan sektor ke- $i$ $\mathrm{TFL} i j=$ total keterkaitan ke depan 
(penjumlahan dari keterkaitan langsung ke depan dan keterkaitan tidak langsung ke depan) dari sektor $i$ ke sektor $j$

$=$ jumlah sektor dalam tabel input output yang dianalisis

\section{HASIL DAN PEMBAHASAN}

Informasi mengenai distribusi manfaat pembangunan perikanan dan industri pengolahan hasil perikanan terhadap perkembangan pembangunan di sektor lainnya melalui transaksi pasar input lazimnya diukur dengan indeks keterkaitan total ke belakang (daya penyebaran total), sedangkan derajat kepekaan sub sektor perikanan dan industri pengolahan hasil perikanan terhadap perubahan yang terjadi pada sektor ekonomi lainnya melalui indeks keterkaitan total ke depan (derajat kepekaan total). Berikut ini diuraikan secara rinci hasil analisis kedua indeks tersebut.

\section{Keterkaitan Total ke Belakang}

Dengan memperhatikan besaran indeks keterkaitan total ke belakang (daya penyebaran total) pada Tabel 2 dan Gambar 1, dapat diketahui bahwa selama kurun waktu 10 tahun (sejak tahun 1990 hingga 2000), kelompok perikanan primer baik perikanan laut maupun perikanan darat belum mampu menunjukkan keterkaitan total ke belakang (daya penyebaran total) yang lebih besar dari rata-rata keseluruhan sektor dalam perekonomian nasional. Hal ini ditunjukkan dari besaran indeksnya yang masih di bawah 1 (satu) dan hanya menempati peringkatan antara 6 (enam) hingga 8 (delapan). Lebih lanjut bila dilihat dari arah dan besaran perubahannya, ternyata selama kurun waktu tersebut secara relatif perikanan darat menunjukkan perkembangan yang lebih baik dibanding perikanan laut, di mana perubahan indeks keterkaitan total ke belakang (daya penyebaran total) untuk sub sektor perikanan darat dari periode 1990-1995 ke 1995-2000 bergeser dari sebesar 5,06\% menjadi sebesar $9,01 \%$, sedangkan perikanan laut bergeser dari sebesar $6,04 \%$ menjadi sebesar $-5,82 \%$.

Berbeda halnya dengan kelompok perikanan sekunder, khususnya untuk industri pengolahan dan pengawetan ikan selama kurun waktu yang sama (selama 10 tahun sejak 1990 hingga 2000) masih menunjukkan

Tabel 2. Indeks dan Peringkat Keterkaitan Total ke Belakang Sektor di Kelompok Perikanan Primer dan Perikanan Sekunder serta Sektor Lainnya dalam Perekonomian Indonesia Tahun 1990, 1995 dan 2000

Table 2. Index and Rank of Total Backward Linkage of Primary and Secondary Fisheries and Other Sectors in Indonesian Economy, 1990,1995 and 2000.

\begin{tabular}{|c|c|c|c|c|c|}
\hline \multirow[b]{2}{*}{ Sektor/Sectors } & \multirow[b]{2}{*}{1990} & \multirow[b]{2}{*}{1995} & \multirow[b]{2}{*}{2000} & \multicolumn{2}{|c|}{ Perubahan/Changes (\%) } \\
\hline & & & & 1990-1995 & $1995-2000$ \\
\hline $\begin{array}{l}\text { Pertanian Non Perikanan/ } \\
\text { Agriculture Non Fisheries }\end{array}$ & 0,51381 (9) & $0,71055(7)$ & $0,72705(7)$ & 38,29 & 2,32 \\
\hline \multicolumn{6}{|l|}{$\begin{array}{l}\text { Perikanan Primer/Primary } \\
\text { Fisheries: }\end{array}$} \\
\hline $\begin{array}{l}\text { - Perikanan Laut / Marine } \\
\text { Fisheries }\end{array}$ & $0,76003(6)$ & $0,71415(6)$ & $0,67262(8)$ & 6,04 & $-5,82$ \\
\hline $\begin{array}{l}\text { - Perikanan Darat / Inland } \\
\text { fisheries }\end{array}$ & $0,63184(7)$ & $0,66383(8)$ & $0,72362(6)$ & 5,06 & 9,01 \\
\hline
\end{tabular}


Tabel 2. lanjutan/Table 2. continued

\begin{tabular}{|c|c|c|c|c|c|}
\hline \multirow[b]{2}{*}{ Sektor/Sectors } & \multirow[b]{2}{*}{1990} & \multirow[b]{2}{*}{1995} & \multirow[b]{2}{*}{2000} & \multicolumn{2}{|c|}{ Perubahan/Changes (\%) } \\
\hline & & & & $1990-1995$ & $1995-2000$ \\
\hline \multicolumn{6}{|l|}{$\begin{array}{l}\text { Perikanan Sekunder/ } \\
\text { Secondary Fisheries: }\end{array}$} \\
\hline $\begin{array}{l}\text { - Industri Pengeringan } \\
\text { dan Penggaraman Ikan/ } \\
\text { Drying and Salting } \\
\text { Processing Industries }\end{array}$ & $0,60122(8)$ & $0,63805(9)$ & 0,63025 (9) & 6,13 & $-1,22$ \\
\hline $\begin{array}{l}\text { - Industri Pengolahan } \\
\text { dan Pengawetan } \\
\text { Ikan/Processing and } \\
\text { Preserving Industries }\end{array}$ & $1,03457(5)$ & $1,00727(5)$ & $1,01522(5)$ & $-2,64$ & 0,79 \\
\hline $\begin{array}{l}\text { Pertambangan dan Galian/ } \\
\text { Mining and Quarrying }\end{array}$ & $1,62345(1)$ & $1,31610(3)$ & $1,28206(3)$ & 18,93 & $-2,59$ \\
\hline $\begin{array}{l}\text { Industri Pengolahan Hasil } \\
\text { Pertanian Non Perikanan/ } \\
\text { Agriculture Non Fisheries } \\
\text { Processing Industries }\end{array}$ & $1,15091(4)$ & $1,43027(1)$ & $1,40399(2)$ & 24,27 & $-1,84$ \\
\hline $\begin{array}{l}\text { Industri Pengolahan Lainnya/ } \\
\text { Other Processing Industries }\end{array}$ & $1,24345(3)$ & $1,12894(4)$ & $1,11752(4)$ & $-9,21$ & $-1,01$ \\
\hline $\begin{array}{l}\text { Jasa-Jasa dan Lainnya/ } \\
\text { Services and Others }\end{array}$ & $1,44072(2)$ & $1,39084(2)$ & $1,42768(1)$ & $-3,46$ & 2,65 \\
\hline
\end{tabular}

Sumber : Hasil Pengolahan Data Tabel Input Output Tahun 1990, 1995 dan 2000

Source : Results of Data Processing of Input Output Table 1990, 1995 and 2000

Keterangan: Angka dalam kurung (...) menunjukkan peringkat besaran indeks keterkaitan total ke belakang (daya penyebaran total)

Remarks : (....) is rank of backward linkage index

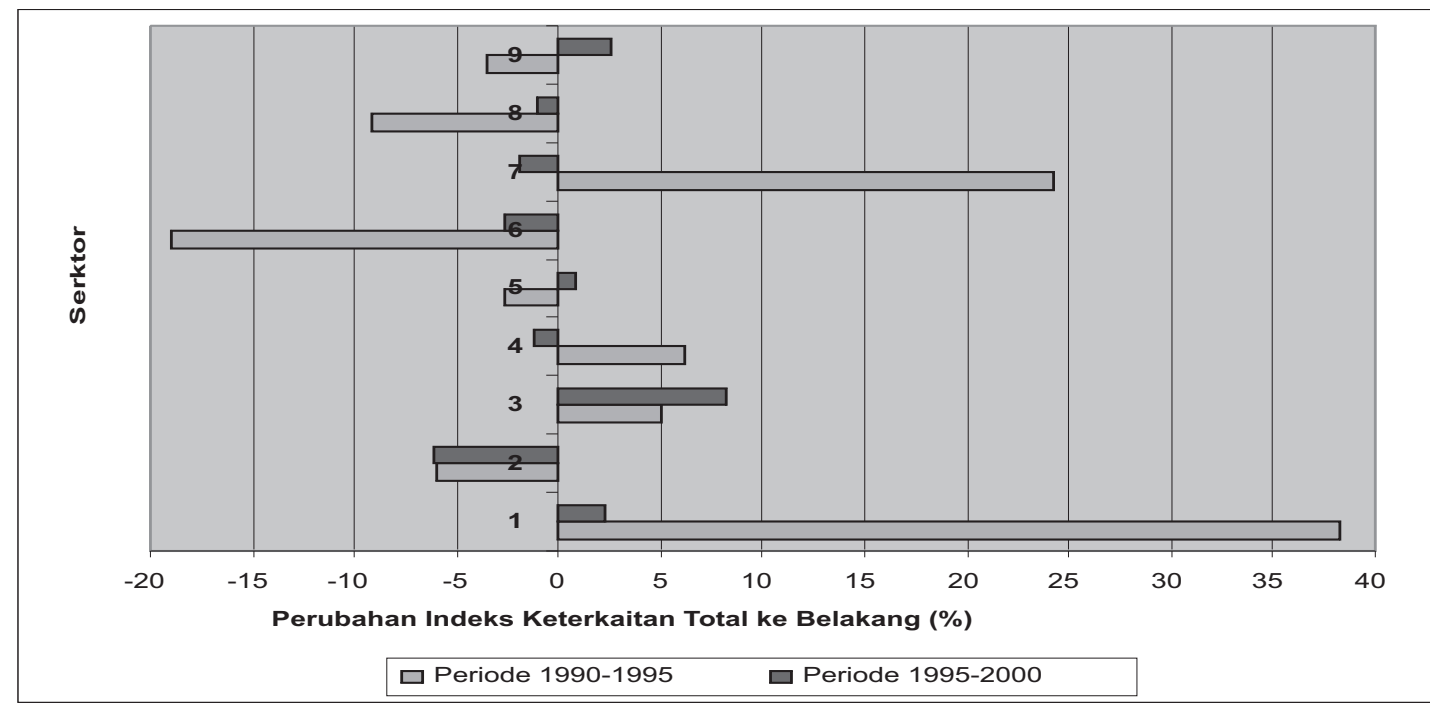

Gambar 1. Perubahan Indeks Keterkaitan Total ke Belakang dari Sub Sektor Kelompok Perikanan Primer dan Perikanan Sekunder serta Sektor Lainnya dalam Perkonomian Indonesia pada Periode 1990-1995 dan 1995-2000.

Figure 1. Index Change of Backward Linkage of Primary Fisheries and Secondary Fisheries and Other Sectors in Indonesian Economy, 1990-1995 and 1995-2000. 
Keterangan/Remarks:

Sektor-1 = Pertanian Non Perikanan/Sector -1 = Agriculture Non Fisheries

Sektor-2 = Perikanan Laut/Sector -2 = Marine Fisheries

Sektor-3 = Perikanan Perikanan Darat/Sector $-3=$ Inland Fisheries

Sektor-4 = Industri Pengeringan dan Penggaraman Ikan/Sector -4 = Drying and Salting Fisheries Processing Industries

Sektor-5 = Industri Pengolahan dan Pengawetan Ikan/Sector -5 = Processing and Preserving Fisheries Industries

Sektor-6 = Pertambangan dan Penggalian/Sector -6 = Mining and Quarrying

Sektor-7 = Industri Pengolahan Hasil Pertanian Non Perikanan / Sector - 7 = Agriculture Non Fisheries Processing Industries

Sektor-8 = Industri Pengolahan Lainnya/Sector -8 = OtherProcessing Industries

Sektor-9 = Jasa-Jasa dan Lainnya/Sector -9 = Services and Others

keterkaitan total ke belakang (daya penyebaran total) yang lebih besar dari ratarata keseluruhan sektor dalam perekonomian nasional dengan peringkat ke-5 (lima) pada setiap tahun analisis, sedangkan untuk sub sektor industri pengeringan dan penggaraman ikan di bawah rata-rata keseluruhan sektor dengan peringkat antara 8 (delapan) dan 9 (sembilan).

Namun demikian, dari Tabel 2 dan Gambar 1 terlihat bahwa kinerja keterkaitan total ke belakang (daya penyebaran total) kedua industri di perikanan sekunder, dalam perkembangannya menunjukkan kecenderungan yang berbeda. Untuk industri pengeringan dan penggaraman ikan berubah dengan kecenderungan yang menurun, yaitu dari sebesar $6,13 \%$ menjadi $-1,22 \%$, sedangkan untuk industri pengolahan dan pengawetan ikan berubah dengan kecenderungan yang meningkat, yaitu dari sebesar $-2,64 \%$ menjadi $0,79 \%$.

\section{Keterkaitan Total ke Depan}

Dari Tabel 3 diketahui bahwa selama kurun waktu 10 tahun (sejak tahun 1990

Tabel 3. Indeks dan Peringkat Keterkaitan Total ke Depan Sub Sektor di Kelompok Perikanan Primer, Kelompok Perikanan Sekunder dan Keseluruhan Sektor Dalam Perekonomian Indonesia, Tahun 1990, 1995 dan 2000

Table 3. Index and Rank of Total Forward Linkage of Primary Fisheries, Secondary Fisheries and All Sectors in Indonesian Economy, 1990,1995 and 2000

\begin{tabular}{|c|c|c|c|c|c|}
\hline \multirow{3}{*}{ Sektor/Sector } & \multirow{3}{*}{1990} & \multirow{3}{*}{1995} & \multirow{3}{*}{2000} & \multicolumn{2}{|c|}{ Perubahan (\%) } \\
\hline & & & & \multicolumn{2}{|c|}{ Change(\%) } \\
\hline & & & & $1990-1995$ & $1995-2000$ \\
\hline $\begin{array}{l}\text { Pertanian Non Perikanan/ } \\
\text { Agriculture Non Fisheries }\end{array}$ & $2,60426(1)$ & 1,16118 (1) & $1,06642(2)$ & $-55,41$ & $-8,16$ \\
\hline \multicolumn{6}{|l|}{ Perikanan Primer / Primary } \\
\hline \multicolumn{6}{|l|}{ Fisheries: } \\
\hline & $0,96617(4)$ & $1,09697(4)$ & $0,93855(6)$ & 13,54 & $-14,44$ \\
\hline $\begin{array}{l}\text { - Perikanan Darat/ Inland } \\
\text { Fisheries }\end{array}$ & $0,58014(7)$ & $0,79563(7)$ & $0,66314(9)$ & 37,14 & $-16,65$ \\
\hline \multicolumn{6}{|l|}{$\begin{array}{l}\text { Perikanan Sekunder/ } \\
\text { Secondary Fisheries: }\end{array}$} \\
\hline $\begin{array}{l}\text { - Industri Pengeringan } \\
\text { dan Penggaraman Ikan/ } \\
\text { Drying and Salting } \\
\text { Processing Industries }\end{array}$ & $0,81989(5)$ & $0,92178(6)$ & $1,02526(3)$ & 12,43 & 11,23 \\
\hline $\begin{array}{l}\text { - Industri Pengolahan } \\
\text { dan Pengawetan Ikan/ } \\
\text { Processing and } \\
\text { Preserving Industries }\end{array}$ & $0,46397(9)$ & $0,53126(9)$ & $0,76538(7)$ & 14,50 & 44,07 \\
\hline
\end{tabular}


Tabel 3. lanjutan/Table 3. continued

\begin{tabular}{|c|c|c|c|c|c|}
\hline \multirow{3}{*}{ Sektor/Sector } & \multirow{3}{*}{1990} & \multirow{3}{*}{1995} & \multirow{3}{*}{2000} & \multirow{2}{*}{\multicolumn{2}{|c|}{$\begin{array}{c}\text { Perubahan (\%)/ } \\
\text { Change(\%) }\end{array}$}} \\
\hline & & & & & \\
\hline & & & & $1990-1995$ & $1995-2000$ \\
\hline $\begin{array}{l}\text { Pertambangan dan Galian/ } \\
\text { Mining and Quarrying }\end{array}$ & $0,48228(8)$ & $0,56271(8)$ & $0,71583(8)$ & 16,68 & 27,21 \\
\hline $\begin{array}{l}\text { Industri Pengolahan Hasil } \\
\text { Pertanian Non Perikanan / } \\
\text { Agriculture non Fisheries } \\
\text { Processing Industries }\end{array}$ & $0,80204(6)$ & $1,02188(5)$ & $1,02009(4)$ & 27,41 & $-0,18$ \\
\hline $\begin{array}{l}\text { Industri Lainnya/ } \\
\text { Other Industries }\end{array}$ & $1,09902(3)$ & $1,33513(3)$ & $1,01093(5)$ & 21,48 & $-24,28$ \\
\hline $\begin{array}{l}\text { Jasa dan Sektor Lainnya/ } \\
\text { Services and Others }\end{array}$ & $1,18224(2)$ & $1,57345(2)$ & $1,79440(1)$ & 33,09 & 14,04 \\
\hline
\end{tabular}

Sumber: Hasil Pengolahan Data Tabel Input Output Tahun 1990, 1995 dan 2000

Source : Data Processing of Input Output Table 1990,1995 and 2000

Keterangan: Angka dalam Kurung (...) Menunjukkan Peringkat Besaran Indeks Keterkaitan ke Depan (derajat kepekaan)

Remarks : (...) is Rank of Forward Linkage Index

hingga 2000) berdasarkan besaran indeks keterkaitan total ke depan (derajat kepekaan total), perikanan laut memiliki keterkaitan total ke depan (derajat kepekaan total) yang mendekati rata-rata keseluruhan sektor dalam perekonomian nasional dengan peringkat antara 4 (empat) dan 6 (enam), bahkan untuk tahun 1995 mampu mencapai lebih besar dari rata-rata keseluruhan yang menduduki peringkat ke- 4 (empat).

Kondisi keterkaitan total ke depan (derajata kepekaan total) yang serupa dengan kelompok perikanan primer (perikanan laut dan perikanan darat) terjadi pada kelompok perikanan sekunder (industri pengeringan dan penggaraman ikan dan industri pengolahan dan pengawetan ikan). Selama kurun waktu 10 tahun (sejak tahun 1990 hingga 2000), besaran indeks keterkaitan total ke depan (derajat kepekaan total) industri pengeringan dan penggaraman ikan mendekati rata-rata keseluruhan sektor dalam perekonomian nasional dengan peringkat antara 3 (tiga) dan 6 (enam), bahkan untuk tahun 2000 sempat lebih besar dari rata-rata keseluruhan yang menduduki peringkat ke 3 (tiga). Namun bila dibandingkan berdasarkan kecenderungan perubahan keterkaitan total ke depan (derajat kepekaan total) kelompok perikanan primer, kondisi perubahan yang sebaliknya justru terjadi pada kelompok perikanan sekunder. $\mathrm{Di}$ kelompok perikanan sekunder ini secara relatif mampu menunjukkan keterkiatan total ke depan (derajat kepekaan total) yang semakin meningkat terutama untuk industri pengolahan dan pengawetan ikan yang meningkat dari perubahan sebesar $14,50 \%$ pada periode 1990-1995 menajadi sebesar 44,07\% pada periode 1995-2000, sedangkan untuk indeks keterkaitan tersebut pada industri pengeringan dan penggaraman ikan relatif tetap atau berubah menurun dengan kisaran yang relatif sangat rendah.

Selanjutnya bila dilihat dari arah dan besaran perubahannya (Tabel 3 dan Gambar 2 ) , ternyata selama kurun waktu tersebut (dari periode 1990-1995 ke 1995-2000), baik perikanan laut maupun perikanan darat 


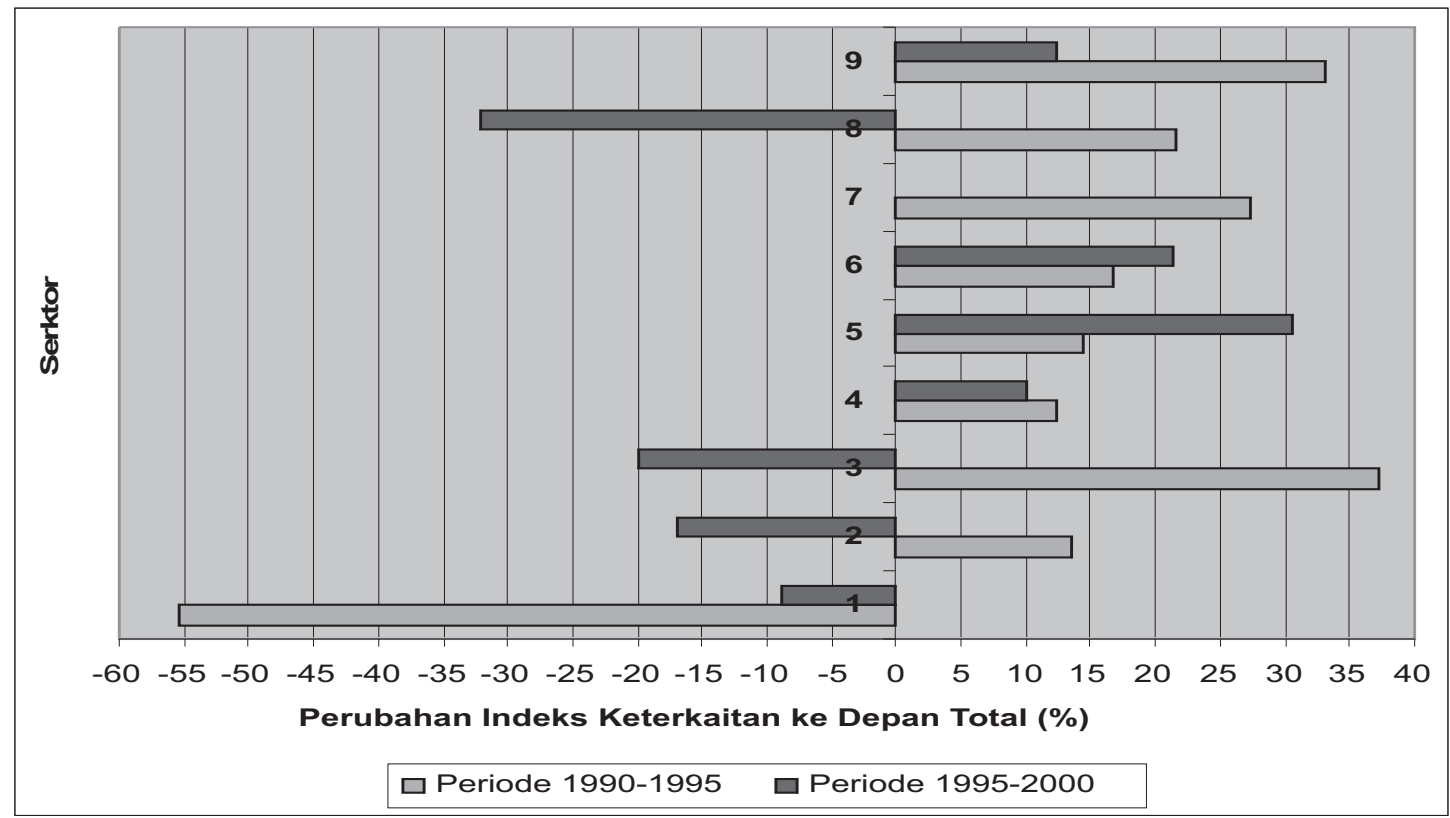

Gambar 2. Perubahan Indeks Keterkaitan Total ke Depan dari Sub Sektor Kelompok Perikanan Primer dan Perikanan Sekunder serta Sektor Lainnya dalam Perkonomian Indonesia pada Periode 1990-1995 dan 1995-2000.

Figure 2. Index Change of Total Forward Linkage of Primary and Secondary Fisheries and Other ISectors in Indonesian Economy, 1990-1995 and 1995-2000

Keterangan/Remarks:

Sektor-1 = Pertanian Non Perikanan/Sector -1 = Agriculture Non fisheries

Sektor-2 = Perikanan Laut/Sector $-2=$ Marine Fisheries

Sektor-3 = Perikanan Perikanan Darat/Sector $-3=$ Inland Fisheries

Sektor-4 = Industri Pengeringan dan Penggaraman Ikan/Sector -4 = Drying and SaltingFisheries Processing Industries

Sektor-5 = Industri Pengolahan dan Pengawetan Ikan/Sector -5 = Processing and Preserving Fisheries Industries

Sektor-6 = Pertambangan dan Penggalian/Sector -6 = Mining and Quarrying

Sektor-7 = Industri Pengolahan Hasil Pertanian Non Perikanan/Sector -7 = Agriculture Non Fisheries Processing Industries

Sektor-8 = Industri Pengolahan Lainnya/Sector $-8=$ OtherProcessing Industries

Sektor-9 = Jasa-Jasa dan Lainnya/Sector -9 = Services and Others

menunjukkan perkembangan kinerja keterkaitan total ke depan (derajat kepekaan total) yang semakin menurun. Hal ini ditunjukkan dari besaran indeks keterkaitan total ke belakang (daya penyebaran total) sub sektor perikanan laut yang menurun dari sebesar 13,54 \% menjadi sebesar $-14,44 \%$, dan dari sebesar $37,14 \%$ menjadi sebesar $16,65 \%$ untuk sub sektor perikanan darat.

\section{Keterkaitan Perikanan Primer dan Perikanan Sekunder}

Dengan menggunakan besaran koefisien dari hubungan keterkaitan total ke belakang dan ke depan antara sub sektor di kelompok perikanan primer (perikanan laut dan perikanan darat) dengan sub sektor di kelompok perikanan sekunder (industri pengeringan dan penggaraman ikan dan industri pengolahan dan pengawetan ikan), khususnya yang dihasilkan dari matriks inverse Leontief --bukan dari matriks koefisien teknis karena menghasilkan koefisien secara keseluruhan sebesar nol-- seperti tertera pada Tabel 4, dapat diketahui bahwa keterkaitan ke depan dari sub sektor di kelompok perikanan primer ke sub sektor di kelompok perikanan sekunder jauh lebih kuat dibandingkan dengan 
Tabel 4. Koefisien Keterkaitan Ke belakang dan ke depan antara Sub Sektor di Kelompok Perikanan Primer dengan Sub Sektor di Kelompok Perikanan Sekunder, Indonesia, 1990, 1995 dan 2000

Table4. Coefficient of Backward and Forward Linkage Between Primary Fisheries and Secondary Fisheries in Indonesia, 1990, 1995 and 2000

\begin{tabular}{|c|c|c|c|c|c|}
\hline $\begin{array}{r}\text { Arah Ke } \\
\text { Direction }\end{array}$ & $\begin{array}{l}\text { orkaitan/ } \\
\text { of Linkage }\end{array}$ & 1990 & 1995 & 2000 & $\begin{array}{l}\text { Kecenderungan } \\
\text { Perubahan I } \\
\text { Trend of Change }\end{array}$ \\
\hline $\begin{array}{l}\text { A. Keterkaitan ke Belakang/ } \\
\text { Backward Linkage } \\
\text { - Dari PIL ke IKG } \\
\text { - Dari PIL ke IOA } \\
\text { - Dari PID ke IKG } \\
\text { - Dari PID ke IOA }\end{array}$ & $\begin{array}{l}\text { A. Keterkaitan ke Depan/ } \\
\text { Forward Linkage } \\
\text { - Dari IKG ke PIL } \\
\text { - Dari IOA ke PIL } \\
\text { - Dari IKG ke PID } \\
\text { - Dari IOA ke PID }\end{array}$ & $\begin{array}{l}0,0000186 \\
0,0000331 \\
0,0000136 \\
0,0000534\end{array}$ & $\begin{array}{l}0,0000020 \\
0,0000509 \\
0,0000152 \\
0,0000697\end{array}$ & $\begin{array}{l}0,0004945 \\
0,0007763 \\
0,0003496 \\
0,0004648\end{array}$ & $\begin{array}{l}\text { Meningkat/Increased } \\
\text { Meningkat/Increased } \\
\text { Meningkat/Increased } \\
\text { Meningkat/Increased }\end{array}$ \\
\hline $\begin{array}{l}\text { B. Keterkaitan ke Depan/ } \\
\text { Forward Linkage } \\
\text { - Dari PIL ke IKG } \\
\text { - Dari PIL ke IOA } \\
\text { - Dari PID ke IKG } \\
\text { - Dari PID ke IOA }\end{array}$ & $\begin{array}{l}\text { B. Keterkaitan ke Belakang/ } \\
\text { Backward Linkage } \\
\text { - Dari IKG ke PIL } \\
\text { - Dari IOA ke PIL } \\
\text { - Dari IKG ke PID } \\
\text { - Dari IOA ke PID }\end{array}$ & $\begin{array}{l}0,7593945 \\
0,0176553 \\
0,2678837 \\
0,1245049\end{array}$ & $\begin{array}{l}0,0273706 \\
0,7011443 \\
0,0185024 \\
0,3156189\end{array}$ & $\begin{array}{l}0,0221332 \\
0,4863083 \\
0,0166889 \\
0,2564997\end{array}$ & $\begin{array}{l}\text { Menurun/Decreased } \\
\text { Fluktuatif/Fluctuated } \\
\text { Menurun/Decreased } \\
\text { Fluktuatif/Fluctuated }\end{array}$ \\
\hline
\end{tabular}

Sumber: Hasil Pengolahan Data Tabel Input Output Tahun 1990, 1995 dan 2000

Source : Data Processing of Input Output Table 1990, 1995 and 2000

Keterangan: PIL: Sub sektor perikanan laut dan hasil perairan laut lainnya; PID: Sub sektor perikanan darat dan hasil perairan darat lainnya; IKG: Sub sektor industri pengeringan dan penggaraman ikan dan biota perairan lainnya; IOA: Sub sektor industri pengolahan dan pengawetan Ikan dan biota perairan lainnya

Remarks : PIL: Sub sector of marine fisheries and result; PID : sub sector of inland fisheries and result; IKG : sub sector of drying and salting industries; IOA: sub sector of processing and preserving industries.

keterkaitan ke belakangnya, atau dengan kata lain keterkaitan ke belakang dari sub sektor di kelompok perikanan sekunder jauh lebih kuat dibandingkan dengan keterkaitan ke belakangnya. Keterkaitan antara kedua kelompok perikanan tersebut lebih mencerminkan keterkaitan ke depan (dibandingkan ke belakang) dari kelompok perikanan primer ke kelompok perikanan sekunder berupa aliran pasokan komoditas ikan untuk bahan baku.

Kisaran nilai koefisien untuk keterkaitan ke depan dari kelompok perikanan primer ke kelompok perikanan sekunder berkisar sebesar 0,0166889 hingga 0,7593945, sedangkan untuk keterkaitan ke belakangnya berkisar sebesar 0,0000020 hingga 0,0007763. Namun bila dilihat dari kecenderungan perubahannya, ternyata untuk keterkaitan ke depan antara perikanan darat dan perikanan laut dengan industri pengeringan dan penggaraman ikan cenderung menurun, sedangkan antara perikanan darat dan perikanan laut dengan industri pengolahan dan pengawetan ikan cenderung berfluktuasi, sedangkan untuk keterkaitan ke belakang seluruhnya baik antara perikanan laut dan perikanan darat dengan industri pengeringan dan penggaraman ikan maupun dengan industri pengolahan hasil perikanan cenderung meningkat.

\section{KESIMPULAN DAN IMPLIKASI KEBIJAKAN}

\section{Kesimpulan}

Selama periode 1990-2000, secara rata-rata keterkaitan sektor perikanan dalam 


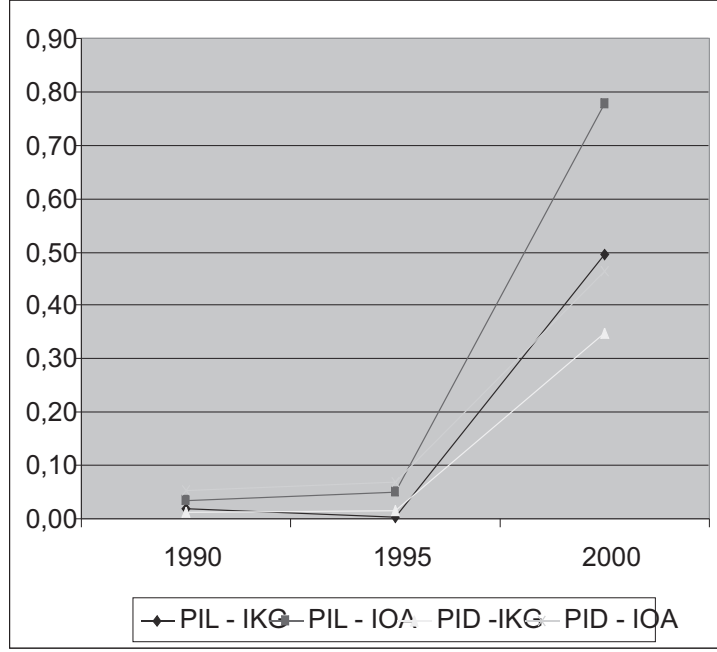

Gambar 3. Kecenderungan Perubahan Koefisien Keterkaitan ke Belakang Antar Sub Sektor dalam Sektor Perikanan

Figure 3.Change Coefficient Trend of Backward Linkage Among Sub Sectors in Fisheries Sector

perekonomian nasional masih relatif lemah, karena selama periode tersebut kecuali industri pengolahan dan pengawetan ikan memiliki indeks keterkaitan lebih rendah dari rata-rata keseluruhan sektor dalam perekonomian (di bawah satu). Kecenderungan penguatan keterkaitan ke belakang terjadi pada perikanan darat dengan indeks yang meningkat dari sebesar 5,06\% pada periode 1990-1995 menjadi sebesar $9,10 \%$ pada periode $1995-2000$. Sedangkan penguatan keterkaitan ke depan terjadi pada industri pengolahan dan pengawetan ikan dengan indeks yang meningkat dari sebesar $14,50 \%$ pada periode 1990-1995 menjadi sebesar 44,07\% pada periode 1995-2000. Keterkaitan ke depan dari kelompok perikanan primer ke kelompok perikanan sekunder jauh lebih kuat dibandingkan dengan keterkaitan ke belakangnya, atau keterkaitan ke belakang dari kelompok perikanan sekunder jauh lebih kuat dibandingkan dengan keterkaitan ke depannya. Keterkaitan antara kedua kelompok perikanan tersebut lebih

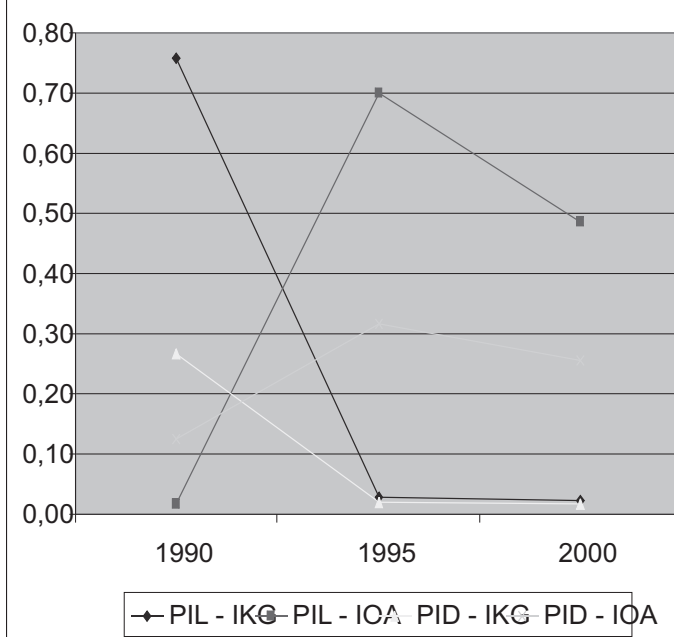

Gambar 4. Kecenderungan Perubahan Koefisien Keterkaitan ke Belakang Antar Sub Sektor dalam Sektor Perikanan

Figure 4. Change Coefficient Trend of Backward Linkage Among Sub Sectors in Fisheries Sector

mencerminkan keterkaitan ke depan (dibandingkan ke belakang) dari kelompok perikanan primer ke kelompok perikanan sekunder berupa aliran pasokan komoditas ikan untuk bahan baku. Namun bentuk keterkaitan ini masih tergolong lemah dan cenderung semakin melemah selama kurun waktu 10 tahun (sejak tahun 1990 hingga 2000).

\section{Implikasi Kebijakan}

Meskipun selama periode 1990-2000 keterkaitan sektor perikanan (baik dari sub sektor di kelompok primer maupun sekunder) yang secara rata-rata masih relatif lemah, namun pada masa mendatang berpotensi menjadi sebagai sektor unggulan (leading sector) nasional, sehingga "jargon" bahwa sektor perikanan sebagai penghela utama (prime mover) perekonomian nasional -terutama untuk tujuan memulihkan perekonomian nasional yang sedang terpuruk-- bukan merupakan slogan semata. Hal ini karena terdapat kecenderungan 
keterkaitan yang semakin menguat dari kedua kelompok perikanan tersebut dalam perekonomian nasional (khususnya perikanan darat untuk keterkaitan ke belakang dan industri pengolahan dan pengawetan ikan untuk keterkaitan ke depan).

Untuk mewujudkan peranan sektor perikanan sebagai sektor unggulan tampaknya tidak dapat terlepas dari upaya mensinergikan antara sub sektor di kelompok perikanan primer dan sub sektor di kelompok perikanan sekunder. Namun yang menjadi pertanyaan adalah bagaimana bentuk sinergi yang harus dilakukan. Dari hasil kajian ini ditemukan bahwa keterkaitan ke depan dari kelompok perikanan primer ke perikanan sekunder jauh lebih kuat dibandingkan dengan keterkaitan ke belakangnya. Oleh karena itu, bentuk sinergis dengan cara mengoptimalkan keterkaitan keterkaitan ke depan dari perikanan primer ke perikanan sekunder, namun tetap mengupayakan penguatan keterkiatan ke belakang, sehingga bentuk sinergi tersebut tidak hanya hubungan ke hilir memposisikan perikanan primer sebagai pemasok bahan baku bagi kegiatan sektor lain, utamanya kelompok perikanan sekunder tetapi juga harus lebih memperkuat hubungan ke hulu.

Melihat fenomena tersebut, terbukti bahwa pengembangan program revitalisasi di bidang perikanan yang telah ditempuh pemerintah merupakan langkah yang tepat, namun akan lebih efektif bila program revitalisasi tersebut dapat lebih mengakomodasi pentingnya pengintegrasian secara vertikal dan sinergis dengan memperkuat bentuk hubungan ke hulu ke hilir antara kegiatan usaha di kelompok perikanan primer (perikanan laut dan perikanan darat) -melalui kegiatan budidaya maupun tangkap sebagai penyedia bahan baku-- dengan kelompok perikanan sekunder sebagai pengguna dari bahan baku tersebut.

\section{DAFTAR PUSTAKA}

Adelman, Irma. 1984. "Beyond Export Leg Growth". World Development report. 12 (9).

Badan Pusat Statistik. 2004. Tabel Input Output Indonesia Updatting Tahun 2003. Jakarta: BPS.

Bell, C. and P. Hazell. 1980. Measuring the Inderect Effects on An Agricultural Investment Project on its Surrounding Region. AJAE, 65: 75-86.

Berry, A. 1995. The Contribution of Agricultural to growth: Colombia in Agricultural on the Road to Industrialization. J.W. Mellor. Ed. London: The John Hopkins University Press.

Bhalla, G.S. 1995. Agricultural Growth and Industrial Development in Punjab. In Agricultural on the Road to Industrialization. J.W. Mellor ed. London: The John Hopkins University Press.

Bigsten, A. and P. Collier. 1995. Linkages From Agricultural Growth in Kenya. In Agricultural on the Road Industrialization. J.W. Mellor ed. London: The John Hopkins University Press.

Cavallo, D. and Y. Mundlak. 1982. Agriculture and Economic Growth in An Open Economy: The Case of Argentina. Washington, D.C: IFRI. Research report 35,

Celes, R. and E. Lizano. 1995. Develompent in Costa Rica: The Key Role of Agricultural in Agricultural on the Road to Industrialization. J.W. Mellor. Ed. London: The John Hopkins University Press.

Dahuri, R., Rais I., Ginting, S.P., dan Sitepu, M.J. 2001. Pengelolaan Sumberdaya Wilayah Pesisir dan Lautan Secara Terpadu. Cetakan Kedua, Edisi Revisi. Jakarta: PT. Pradnya Paramita.

Haggblade, S. and P. Hazell. 1989. Agricultural Technology and Farm-Non Farm Growth Linkages. Agricultural Economics: 345-364p. 
Haggblade, S., J. Hammer and P. Hazell. 1991. Modelling Agricultural Growth Multiplier. AJAE, 73: 361-174.

Jhingan, M.L. 1991. Ekonomi Pembangunan dan Perencanaan. Edisi ke delapan. Jakarta: Raja Grafindo Persada.

Kuncoro, M. 2002 ${ }^{\mathrm{a}}$. Metode Kuantitatif: Teori dan Aplikasi Untuk Bisnis dan Ekonomi. Yogyakarta: UPP-AMP-YKPN.

Kuncoro, M. 2002 ${ }^{\mathrm{b}}$. Analisis Struktur-PerilakuKinerja Agroindustri Indonesia: Suatu Catatan Empiris. Kelola Gadjah Mada, University Business Review, 11 (IV).

Mundlak, Y. and R. Donenech. 1995. Agricultural Growth in Argentina. In Agricultural on the Road Industrialization. J.W. Mellor ed. London: The John Hopkins University Press.

Nazara, S. 1997. Analisis Input-Output. Jakarta: Fakultas Ekonomi Universitas Indonesia.
Nikijuluw, V.P.H. 2005. Politik Ekonomi Perikanan: Bagaimana dan Kemana Bisnis Perikanan?. Jakarta: Feraco.

Rangrajan, C. 1982. Agricultural Growth and Industrial Performance in India. Washington, D.C: IFPRI. Research Report, 33.

Sumodiningrat, G. dan Kuncoro, M. 1991. Ekonomi Pertanian di Indonesia: Perkembangan dan Peranan Modeling. Pusat Anatar Universitas. Jakarta: Studi Ekonomi. Universitas Indonesia.

West, G.R. 1992. Input-Output Analysis for Practitioners. Departement of Economic. University of Queensland. 